\title{
Określenie modułu ścinania gruntów mineralnych i organicznych na podstawie badań dylatometrycznych DMT i SDMT
}

\author{
Determination of the shear modulus of mineral and organic soils by dilatometer tests DMT \\ and SDMT
}

\author{
Simon Rabarijoely, Konrad Szczygielski \\ Katedra Geoinżynierii, Szkoła Główna Gospodarstwa Wiejskiego, Warszawa, simon_rabarijoely@sggw.pl
}

Zarys treści: Niniejszy artykuł poświęcony jest analizie warunków geotechnicznych oraz wyznaczeniu zależności, pozwalających na obliczenie modułu ścinania $\mathrm{G}_{0}$ dla gruntów mineralnych i organicznych obiektów zlokalizowanych na terenie kampusu SGGW i osiedla Stegny. We wstępie przedstawiono opis badań standardowym dylatometrem Marchettiego i sejsmicznym dylatometrem SDMT oraz sposób interpretacji uzyskanych wyników. Zaprezentowano także ogólny opis teoretyczny badań sejsmicznych wraz z charakterystyką fal poprzecznych, podłużnych i powierzchniowych, wykorzystywanych w geotechnice. Ponadto omówiono budowę geologiczną i warunki hydrogeologiczne oraz scharakteryzowano parametry geotechniczne na terenie wyżej wymienionych obiektów. Ostatnia część artykułu to propozycja nomogramów klasyfikacyjnych dla gruntów mineralnych i organicznych oraz możliwości wykorzystania modułu ścinania w interpretacji wyników badań SDMT.

Słowa kluczowe: moduł ścinania, badanie sejsmiczne, nomogram klasyfikacyjny, grunty mineralne i organiczne

\begin{abstract}
The paper is devoted to the analysis of the geotechnical conditions and determination of relationships allowing to estimate the shear modulus of mineral and organic soils for sites located in SGGW campus and in Stegny site in Warsaw. In the literature overview there have been presented description of Marchetti Dilatometer test and Seismic Dilatometer test (SDMT) as well as the methodology of these tests and parameters evaluation. Also there have been shown a theoretical description of seismic tests with characteristics of transverse, longitudinal and surface waves used in geotechnics. Furthermore there have been presented geological and hydrogeological structure as well as geotechnical conditions of sites mentioned above. In the last stage of this work there have been proposed relationships and classification charts of mineral and organic soils and the possibilities of using shear modulus.
\end{abstract}

Keywords: shear modulus, SDMT, classification chart, organic and mineral soils

\section{Wprowadzenie}

W obecnych czasach dynamiczne tempo życia często związane jest z koniecznością szybkiego wykonywania projektowanych inwestycji. Wiąże się to jednocześnie ze skróceniem okresu realizacji przedsięwzięcia do minimum, co w efekcie może spowodować powstanie niebezpiecznych osiadań i uszkodzenia konstrukcji.

Jednym ze sposobów badań terenowych wykorzystywanych w praktyce są badania standardowym dylatometrem Marchettiego (DMT) i sejsmicznym dylatometrem (SDMT). Charakteryzują się one przede wszystkim nie- skomplikowanym pomiarem oraz niskim nakładem finansowym. Metody te służą do określania parametrów gruntowych i oceny warunków geotechnicznych, zarówno do obliczeń projektowych, jak i badań kontrolnych w okresie budowy i eksploatacji. Dotychczasowe badania opisane w literaturze dotyczyły głównie gruntów mineralnych. Jednak w Polsce często mamy do czynienia również z gruntami organicznymi, takimi jak gytje czy torfy, które ze względu na swoje właściwości mogą utrudnić prawidłowe zaprojektowanie budowli.

Celem tego artykułu jest analiza warunków geotechnicznych pozwalających na obliczenie modułu ścinania 
$\mathrm{G}_{\mathrm{o}}$ dla gruntów mineralnych i organicznych. Została ona wykonana dla obiektów zlokalizowanych na terenie kampusu Szkoły Głównej Gospodarstwa Wiejskiego (SGGW) w Warszawie, poligonu doświadczalnego na osiedlu Stegny. Jako propozycję zamieszczono algorytm, prezentujący dwie metody na wyznaczenie modułu ścinania $\mathrm{G}_{\mathrm{o}}$. Przedstawione zostały także trzy nomogramy prezentujące moduł ściśliwości M i współczynnik prekonsolidacji OCR w zależności od modułu ścinania $G_{0}$ i wskaźnika naprężenia bocznego $\mathrm{K}_{\mathrm{D}}$ oraz nomogram obrazujący zależność naprężenia prekonsolidacji $\sigma^{\prime}$ od modułu ścinania $\mathrm{G}_{\mathrm{o}}$ i współczynnika prekonsolidacji OCR. Podsumowaniem tego artykułu jest opis korzyści i możliwości, jakie stwarza wyznaczanie modułu ścinania $G_{0}$.

\section{Charakterystyka i właściwości modułu ścinania $G_{0}$}

Prawidłowe zaprojektowanie budowli inżynierskiej wymaga znajomości zachowania się gruntu pod obciążeniem. Do opisu odkształcenia gruntu używane są wskaźniki ściśliwości lub moduły sprężystości. Niezwykle istotne jest więc określenie możliwie jak najbardziej zbliżonych do rzeczywistych wartości modułu odkształcenia w zakresie małych i średnich odkształceń, pojawiających się w gruncie pracującym pod obciążeniem.

Tak więc dla bardzo małych odkształceń stosuje się początkowy moduł odkształcenia $\mathrm{E}_{\mathrm{o}}\left(\mathrm{E}_{\max }\right)$ lub moduł ścinania $\mathrm{G}_{\mathrm{o}}\left(\mathrm{G}_{\max }\right)$. Wielkości te można określić na podstawie pomiaru prędkości fali poprzecznej $\mathrm{V}_{\mathrm{s}}$, którą uzyskuje się w badaniach. Moduł odkształcenia $\mathrm{E}_{\mathrm{o}}$ obliczamy ze wzoru:

$$
E_{0}=2 \cdot \rho \cdot V_{s}^{2} \cdot(1+v)
$$

natomiast moduł ścinania $\mathrm{G}_{\mathrm{o}}$ obliczamy ze wzoru:

$$
G_{0}=\rho \cdot V_{s}^{2}
$$

gdzie:

$\rho\left[\mathrm{t} / \mathrm{m}^{3}\right]$ - gęstość objętościowa gruntu,

$\mathrm{V}_{\mathrm{s}}[\mathrm{m} / \mathrm{s}]$ - prędkość fali poprzecznej,

$v[-]-$ współczynnik Poissona.

Gdy przyjmiemy, że wartość współczynnika Poissona równa jest 0,5 (dla tej wartości propagacja fali przez próbkę gruntu nie powoduje odkształceń objętościowych oraz jest to wartość dla gruntów drobnoziarnistych w warunkach bez odpływu), to możemy pomiędzy powyższymi modułami zaobserwować zależność, która wygląda następująco:

$$
E_{0}=3 \cdot G_{0}
$$

W tym rozdziale w głównej mierze omówiono właściwości modułu ścinania $G_{0}$. Podobnie jak wytrzymałość gruntów, moduł ścinania jest funkcją wielu zmiennych, które zostały przedstawione we wzorze (4) (Hardin, Black 1968). Do czynników, które decydują o wartości modułu $\mathrm{G}_{\mathrm{o}}$ zaliczamy: $\sigma{ }^{\prime}{ }_{\mathrm{o}}$ - efektywne naprężenie oktaedryczne, e - wskaźnik porowatości, $\mathrm{S}$ - stopień nasycenia gruntu, naprężenie dewiatorowe, $\mathrm{C}$ - charakterystyki granulometryczno-mineralogiczne, A - amplituda drgań, F - częstotliwość drgań, T - efekty uzależnione od czasu, $\theta$ - struktura gruntu, $\mathrm{K}$ - temperatura (Hardin, Black 1968):

$$
G_{0}=\mathrm{f}\left(\sigma_{0}^{\prime}, e, S, C, A, F, T, \theta, K\right)
$$

Nie wszystkie wymienione czynniki można i należy uwzględniać, ponieważ nie wpływają one jednakowo na wartość prędkości uzyskiwanej w badaniach (Hardin, Black 1968). Najistotniejszymi czynnikami są naprężenie efektywne i wskaźnik porowatości. Najczęściej podawane są dwie podstawowe zależności (5) i (6) (Hardin, Black 1968, Hardin 1978). W gruntach moduł ścinania jest funkcją stanu naprężenia efektywnego, wskaźnika porowatości, współczynnika prekonsolidacji oraz odkształcenia postaciowego (Shibuya i in. 1992):

$$
\begin{gathered}
G_{0}=A(T) F(e) \sigma^{\prime n} \\
G_{0}=S(T) F(E) \sigma^{\prime n} O C R^{k}
\end{gathered}
$$

Jak wynika z badań laboratoryjnych, zmiana sztywności zachodzi razem ze zmianą stanu odkształcenia postaciowego. Sztywność gruntu w zakresie małych odkształceń jest bardzo ważnym czynnikiem bezpośrednio wpływającym na interakcję konstrukcji budowlanych z otaczającym je gruntem. Warto zaznaczyć, że jest istotnym parametrem przy rozwiązywaniu problemów granicznych wartości, takich jak:

- reakcja sejsmiczna gruntów na trzęsienia ziemi;

- dynamiczna interakcja pomiędzy, gruntem i fundamentami;

- projektowanie specjalnych fundamentów, których granica użytkowalności pozwala na bardzo małe przemieszczenia.

\section{Opis i charakterystyka sondowania dylatometrem standardowym (DMT) i sejsmicznym (SDMT)}

Badanie rozpoczyna się przez wprowadzenie ostrza dylatometru w podłoże gruntowe. Po zagłębieniu ostrza dylatometru w gruncie na żądaną głębokość zwiększa się wolno ciśnienie gazu, powodując w ten sposób ruch membrany w kierunku gruntu. Wartość ciśnienia gazu zwiększa się aż do wychylenia środka membrany o 1,1 mm. Najczęściej wykonuje się dwa pomiary ciśnienia A i B (ryc. 1a, b). Pomiar A odpowiada skorygowanej wartości ciśnienia gazu, otrzymanej w początkowej fazie ruchu membrany prowadzącej do kontaktu z otaczającym grun- 


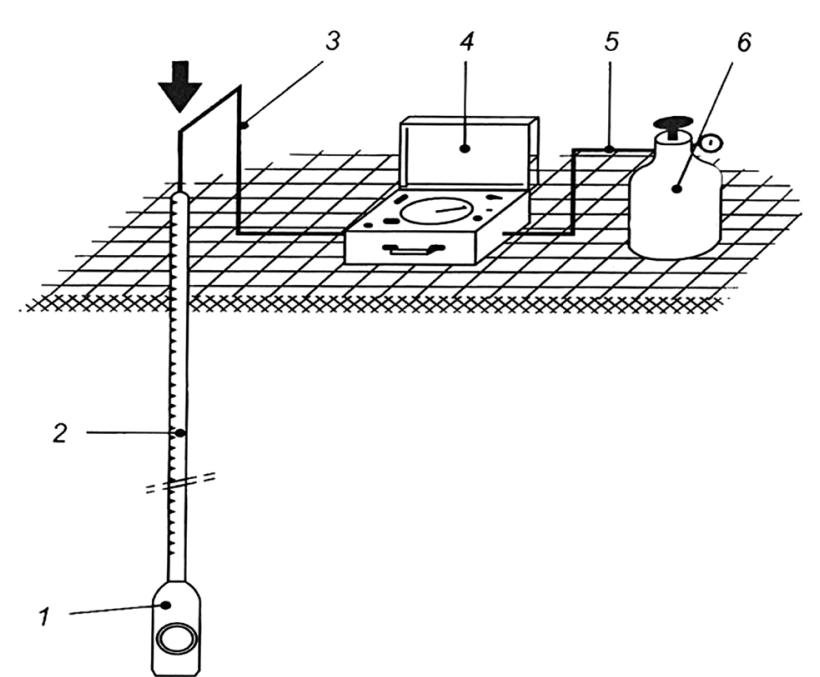

Ryc. 1a. Zestaw pomiarowy dylatometru Marchettiego (1980) w wersji standardowej

1 - ostrze dylatometru, 2 - żerdzie pomiarowe, 3 - rurka pneumatyczno-elektryczna, 4 - system sterująco-pomiarowy, 5 - przewód pneumatyczny, 6 - zbiornik z gazem

Fig. 1a. Marchetti (1980) dilatometer measurement standard set 1 - dilatometer blade, 2 - measuring rods, 3 - pneumatic-electric tube, 4 - a system of unit control measuring, 5 - pneumatic cable, 6 - gas tank

tem - jest to tzw. ciśnienie kontaktowe. Pomiar B wskazuje skorygowaną wartość ciśnienia gazu uzyskaną przy dodatkowym wychyleniu środka membrany w kierunku gruntu o $1,1 \mathrm{~mm}$. Pomiary są wykonywane w stałych odstępach wynoszących $20 \mathrm{~cm}$; w przypadku gruntów słabych pomiary można zagęścić, przeprowadzając je w odstępach $10 \mathrm{~cm}$. Zaleca się dokonywanie dodatkowego pomiaru ciśnienia $\mathrm{C}$ po powrocie membrany do położenia wyjściowego, tzn. do położenia, w którym mierzy się ciśnienie kontaktowe A. Ponadto w celu określenia współczynnika konsolidacji dokonywane są również pomiary

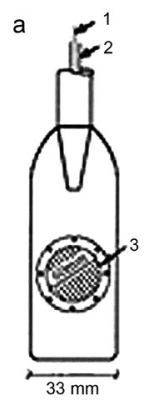

b

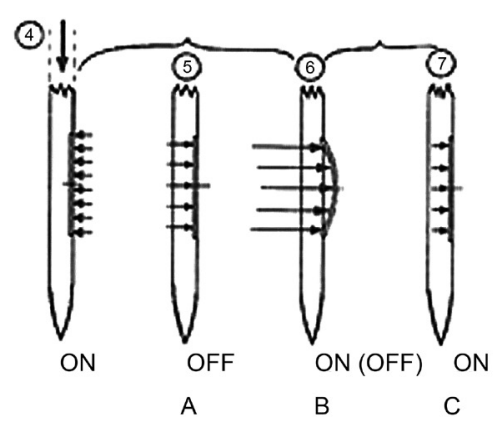

Ryc. 1b. Budowa dylatometru Marchettiego (1980)

a - schemat budowy łopatk: 1 - przewód elektryczny, 2 przewód pneumatyczny, 3 - membrana; b - fazy badania dylatometycznego: 4 - pogrążanie łopatki, 5 - odczyt A, 6 - odczyt B, 7 - odczyt C

Fig. 1b. Marchetti (1980) dilatometer construction a - view of the blade: 1 - electric cable, 2 - pneumatic cable, 3 - membrane; $b$ - dilatometer test phase, 4 - insertion the blade, $5-\mathrm{A}$ reading, $6-\mathrm{B}$ reading, $7-\mathrm{C}$ reading

kontrolowanego w czasie swobodnego rozpraszania ciśnienia po uzyskaniu odczytu C.

Dylatometr sejsmiczny jest połączeniem standardowego dylatometru zaprezentowanego przez Marchettiego (1980) oraz modułu mierzącego prędkość rozchodzenia się fali sejsmicznej $\mathrm{V}_{\mathrm{s}}$. Został zaprezentowany przez Heptona (1988), a następnie udoskonalony na Uniwersytecie Georgia Tech w Atlancie, USA (Martin, Mayne 1997, 1998, Mayne i in. 1999). Nowy układ z sejsmicznym dylatometrem (ryc. 2) został ostatnio opracowany we Włoszech (Marchetti i in. 2008, Amoroso i in. 2012). Moduł sejsmiczny ma kształt walca o średnicy równej średnicy żerdzi CPT i zawiera dwa rejestratory fal sejsmicznych odległe od siebie o $0,5 \mathrm{~m}$. Jest umieszczony powyżej ostrza dylatometru. Sygnał wraz z głębokością wzmacnia się i jest zapisywany cyfrowo.

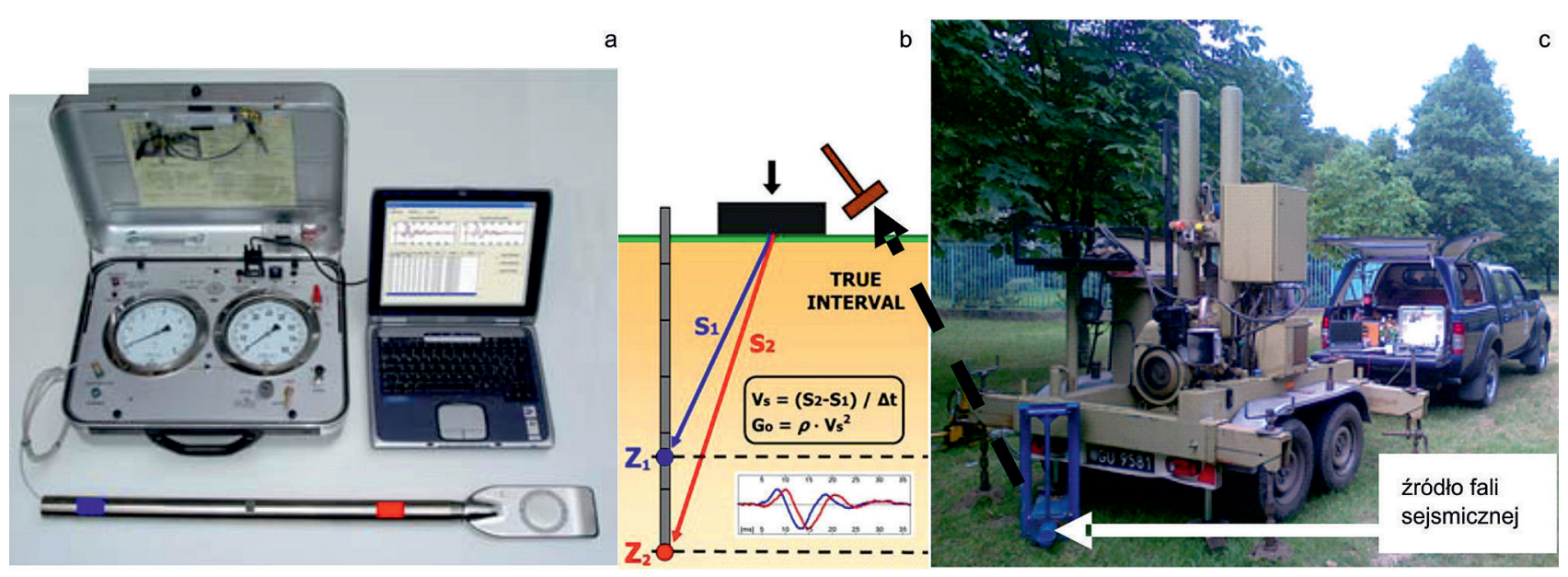

Ryc. 2. Aparatura i sposób prowadzenia badań dylatometrycznych

a - wyposażenie dylatometru sejsmicznego (Monaco i in. 2009), b - plan sondowania SDMT (Monaco i in. 2009), c - źródło fali sejsmicznej na powierzchni (Rabarijoely i in. 2012)

Fig. 2. Apparatus and dilatometer tests method

$\mathrm{a}$ - seismic dilatometer equipment (Monaco et al. 2009), b - SDMT sounding process (Monaco et al. 2009), $\mathrm{c}$ - seismic waves source on the surface (Rabarijoely et al. 2012) 
Tabela 1. Typowe prędkości fal podłużnych i poprzecznych do głębokości 40 metrów (Campanella i Stewart 1992)

Table 1. Typical speeds of longitudinal and transversal waves to a depth of 40 meters (Campanella and Stewart 1992)

\begin{tabular}{lclc}
\hline \multicolumn{1}{c}{ Materiał } & $\mathrm{V}_{\mathrm{s}}\left(\mathrm{ms}^{-1}\right)$ & & Materiał \\
\hline Woda & 0 & Woda & $\mathrm{V}_{\mathrm{p}}\left(\mathrm{ms}^{-1}\right)$ \\
Grunty nasycone & $<50-400$ & Grunty nasycone & 1482 \\
Grunty nienasycone & $<50-200$ & Grunty nienasycone & $1500-1900$ \\
Lekko spoiste grunty & $250-700$ & Powietrze & $<100-600$ \\
Nasycone torfy/grunty organiczne & $<15-200$ & Zgazowane grunty poniżej zwierciadła wód gruntowych & $800-<1500$ \\
\hline
\end{tabular}

Taki układ czujników pozwala na uniknięcie problemów związanych z niejednoznacznym ustaleniem czasu dojścia impulsu sejsmicznego, jaki zdarza się często przy zastosowaniu jednego czujnika. Co więcej, para sejsmogramów zapisanych przez dwa czujniki na zadanej głębokości pokrywa się z tym samym uderzeniem młotka, a nie $\mathrm{z}$ dwoma różnymi sekwencyjnymi uderzeniami, które nie muszą być koniecznie identyczne. W związku z tym powtarzalność pomiarów prędkości rozchodzenia się fali sejsmicznej znacznie się poprawiła (obserwowana $\mathrm{V}_{\mathrm{s}}$ o powtarzalności na poziomie $1-2 \%$ ).

Prędkość rozchodzenia się fali sejsmicznej została przedstawiona na rycinie $1 \mathrm{a}, \mathrm{b}$ i c jako iloraz różnicy odległości między źródłem impulsu sejsmicznego a dwoma odbiornikami $\left(\mathrm{s}_{2}-\mathrm{s}_{1}\right)$ i zmierzonego opóźnienia dotarcia impulsu z pierwszego do drugiego odbiornika $(\Delta \mathrm{t})$. Warto dodać, że pomiar $\mathrm{V}_{\mathrm{s}}$ przypada na każde $0,5 \mathrm{~m}$ głębokości, gdy mechaniczne pomiary DMT są odczytywane co 0,2 m. Impuls sejsmiczny wyzwolony jest przez poziome uderzenie młotem elipsoidalnego stalowego elementu dociśniętego mocno do podłoża (poprzez masę ciężarówki) (ryc. 2). Podłużna oś tego elementu jest umieszczona równolegle do osi czujników sejsmicznych i dlatego są one najbardziej wrażliwe na falę sejsmiczną. Kiedy na powierzchni zostaje wygenerowana fala ścinająca, dociera ona najpierw do pierwszego górnego odbiornika, a następnie z opóźnieniem do niższego odbiornika. Ustalenie opóźnienia na podstawie sejsmogramów SDMT jest zwykle wykonywane przy użyciu algorytmu o krzyżujących się korelacjach. Algorytm ten jest oparty na dwóch sejsmogramach uzyskanych z sondowania SDMT, a w szczególności początkowych falach otrzymywanych podczas badania. Typowe prędkości fal poprzecznych i podłużnych w różnych ośrodkach do głębokości $40 \mathrm{~m}$ zostały przedstawione w tabeli 1 . Warto zauważyć, że wartości te zmieniają się wraz z przeciążającym naprężeniem.

\section{Budowa geologiczna i warunki geotechniczne podłoża}

Kampus SGGW na Ursynowie znajduje się w obrębie wysoczyzny morenowej o płaskiej, przeobrażonej antropogenicznie powierzchni. Na wschód od badanego terenu wysoczyzna opada stromą skarpą na poziom tarasu wyższego - praskiego - doliny Wisły (Sarnacka 1976). W materiałach archiwalnych nie znaleziono map ani szki- ców geomorfologicznych analizowanego w artykule terenu badań w odpowiedniej skali.

Ogólnie dostępne materiały są nieużyteczne ze względu na zbyt małe skale (użyteczna mapa lub szkic geomorfologiczny ze względu na wielkość poligonu badawczego powinien być wykonany w skali 1:10 000 lub większej). Dlatego też mapa taka nie została przedstawiona w artykule. Podłoże osadów czwartorzędowych stanowią tu iły plioceńskie, tworzące w strefie skarpowej doliny Wisły glacitektoniczną kulminację. Ponad nimi występują rzeczne osady preglacjalne, wykształcone w postaci piasków i żwirów kwarcowych z lidytami oraz mułków. Według Różyckiego i Sujkowskiego (1936), w strefie przyskarpowej osady te są także zaburzone. W głębi wysoczyzny, na przykład w rejonie Służewca, osady preglacjalne występują na niezaburzonej powierzchni sedymentacyjnej iłów plioceńskich (Sarnacka 1992). Utwory najstarszego zlodowacenia oraz następującego po nim interglacjału kromerskiego (wg Sarnackiej 1992) nie zostały wykryte w profilu osadów czwartorzędowych w rejonie Ursynowa. Na obszarze Warszawy występują one w obrębie głębokich depresji w powierzchni stropowej utworów plioceńskich (Morawski 1980, Sarnacka 1992). Na osadach preglacjalnych lub bezpośrednio na jeziornych osadach pliocenu leżą na obszarze wysoczyzny ursynowskiej utwory glacjalne zlodowaceń południowopolskich. Wykształcone są one w postaci glin zwałowych, osadów fluwioglacjalnych i zastoiskowych tworzących nieciągłe warstwy. Brak ciągłej pokrywy osadów tego wieku może być związany z późniejszymi procesami erozji rzecznej, przebiegający najintensywniej w interglacjale wielkim, albo z glacitektonicznym wypiętrzeniem strefy przyległej do współczesnej doliny Wisły. Ponad osadami glacjalnymi zlodowaceń południowopolskich występuje 15-25-metrowej miąższości kompleks osadów rzecznych z okresu interglacjału mazowieckiego, wykształconych w postaci piasków i żwirów. Strop tych osadów zalega na głębokościach od 10 do $20 \mathrm{~m}$ poniżej powierzchni terenu (Sarnacka 1992). W rejonie Ursynowa utwory tej serii to głównie piaski drobne tworzące ciągłą warstwę.

$\mathrm{Na}$ osadach interglacjału mazowieckiego występują w rejonie Warszawy serie utworów glacjalnych związanych z transgresją i zanikiem lądolodu zlodowacenia odry. Najniższym ogniwem tej serii są występujące w izolowanych płatów osady zastoiskowe, wykształcone w postaci iłów i mułków osadzonych w obrębie tak zwanego jeziorzyska dolnej Pilicy (Różycki 1972). Ponad nimi leżą piaski i żwiry fluwioglacjalne związane z transgresją lądolodu, które odsłaniają się na przykład w dolnej części 

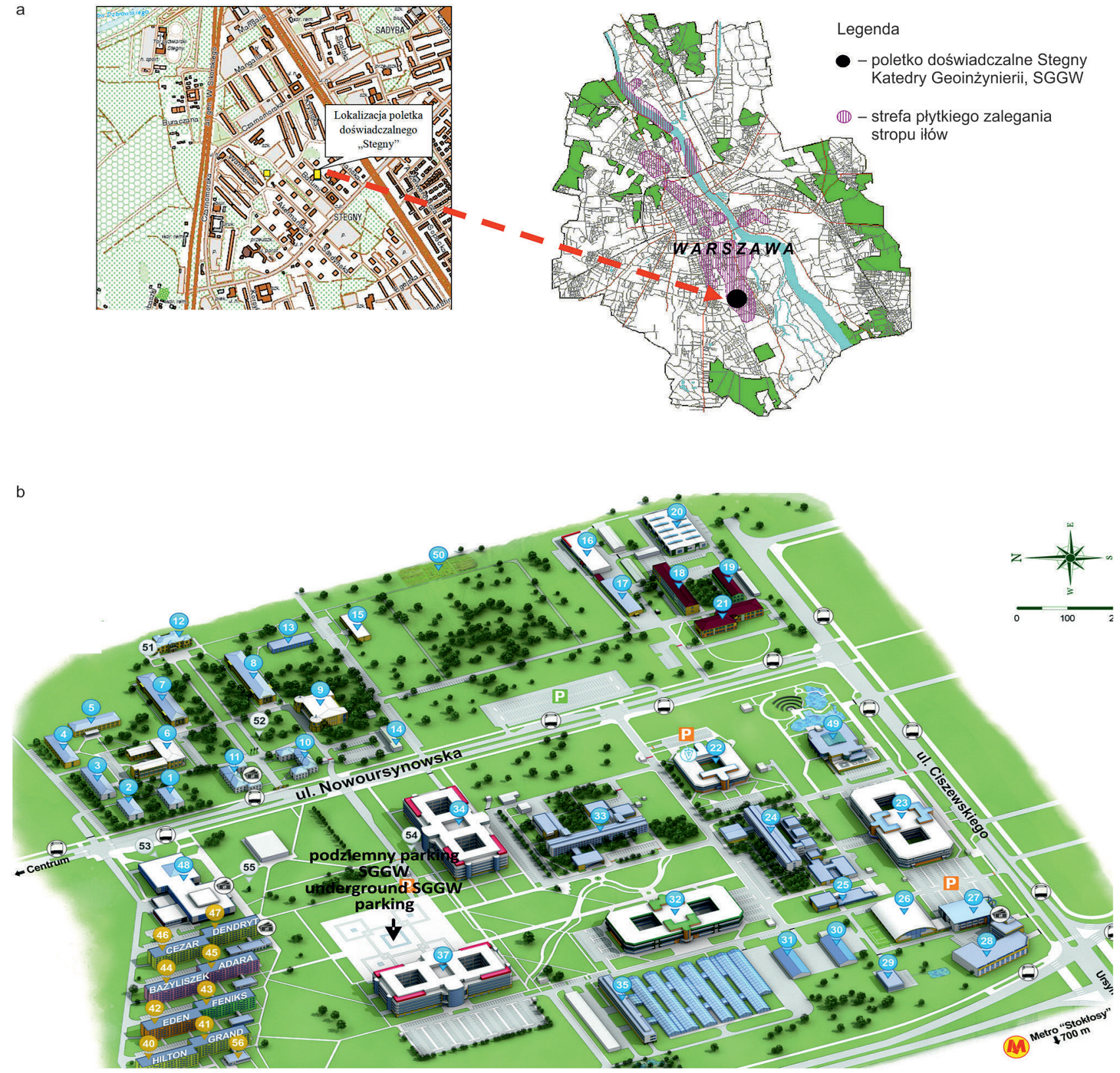

Ryc. 3. Lokalizacja terenu badań na tle miasta Warszawy

Fragment mapy topograficznej Warszawy z wyszczególnionym rejonem: a - poletka doświadczalnego Stegny (Bajda i in. 2008), b - kampusu SGGW

Fig. 3. Location of the site area on the background of the city of Warsaw

Fragment of topographic map of Warsaw specified region: a - Stegny site (Bajda i in. 2008), b - SGGW campus

krawędzi dolinki służewieckiej (Sarnacka 1992). Ponad osadami fluwioglacjalnymi występuje w zasadzie ciągła warstwa utworów wytopnieniowych zlodowacenia odry, wykształconych w postaci ciemnoszarej gliny zwałowej. Miąższość gliny ( $\left.{ }^{\mathrm{g} Q p O}\right)$ wynosi od kilku do kilkudziesięciu metrów (Morawski 1980, Sarnacka 1992). Glinę zwałowa zlodowacenia odry stadiału maksymalnego zlodowacenia środkowopolskiego uważa Morawski (1980) za poziom przewodni na obszarze Warszawy. Buduje go charakterystyczna ciemnoszara, zwarta glina piaszczysta z niewielką liczbą głazików. Glina ta według Morawskiego wykazuje wyraźny cios, przeważnie pionowy. Powierzchnie oddzielności pokryte są rdzawym nalotem.
W NW części wykopu fundamentowego pod budynek Centrum Wodnego Wydziału Budownictwa i Inżynierii Środowiska SGGW strop ciemnoszarej piaszczystej gliny zwałowej (zlodowacenia odry) występuje na głębokości około 4,6 m p.p.t. Stwierdzone na terenie kampusu SGGW deniwelacje w obrębie tej powierzchni dochodzą do $3 \mathrm{~m}$ (ryc. 3).

Ponad gliną zlodowacenia odry ( $\left.{ }^{\mathrm{g} Q p O}\right)$ na terenie Ursynowa występują lokalnie utwory fluwioglacjalne i zastoiskowe. Na nich lub jak w przypadku obszaru kampusu SGGW bezpośrednio na tej glinie leżą gliny lodowcowe zlodowacenia warty. Wykształcone sa one w postaci brązowej, piaszczystej gliny zwałowej o przeciętnych miąż- 


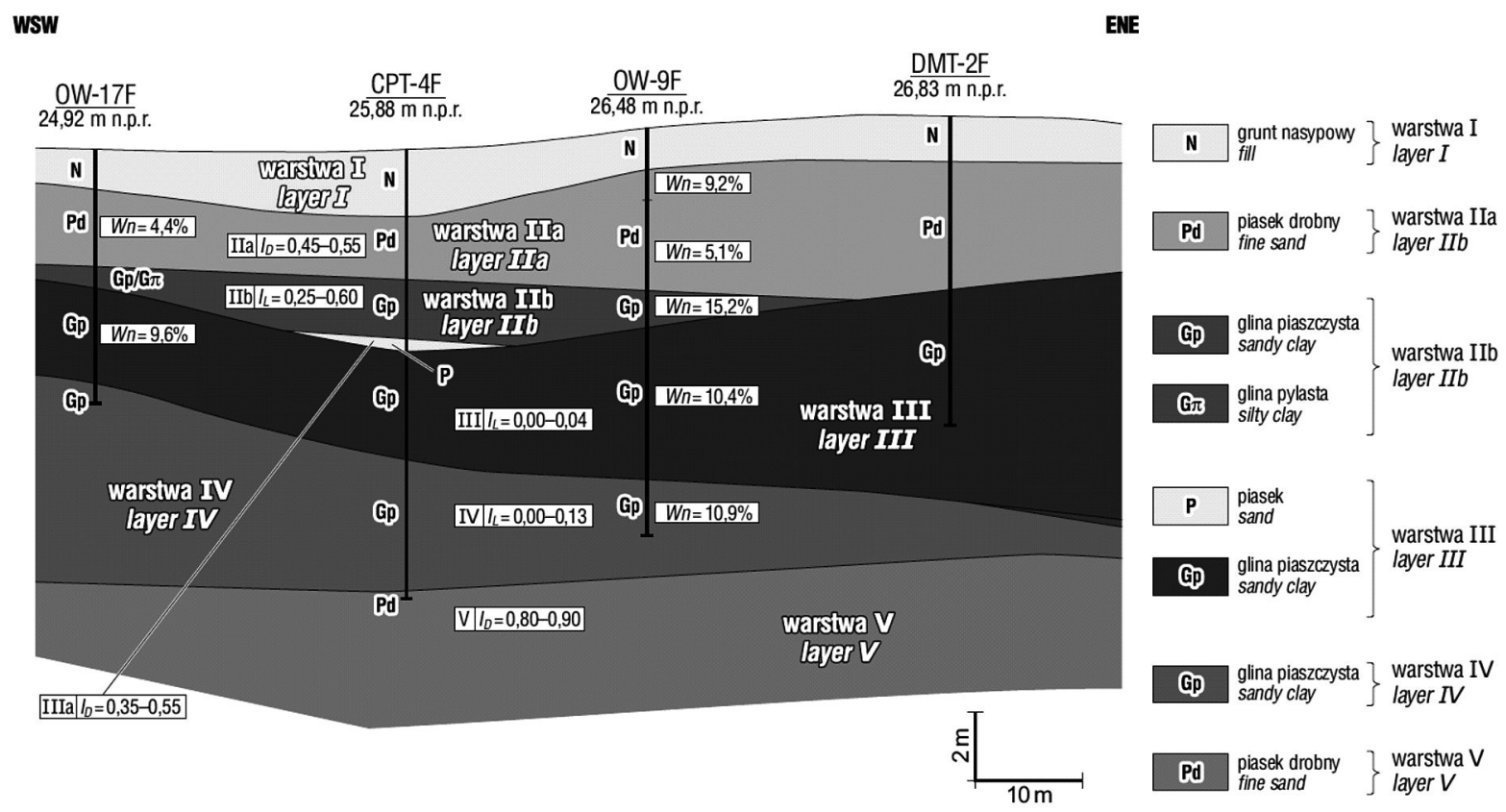

Ryc. 4. Typowy przekrój geotechniczny

( $\mathrm{N}$ - grunt nasypowy, Gp - glina piaszczysta, $\mathrm{Pd}$ - piasek drobny, Wn - wilgotność naturalna, ID - stopień zagęszczenia, IL - stopień plastyczności) - parking podziemny SGGW

Fig. 4. Typical geotechnical cross section

( $\mathrm{N}$ - fill, Gp - sandy clay, Pd - fine sand, Wn - moisture content, ID - relative density, IL - liquidity index) - underground park SGGW

szościach od 2 do 5 m (Sarnacka 1992) ('QpW) (ryc. 4). Granica pomiędzy glinami zlodowaceń odry i warty jest często (tak jak na obszarze Kampusu SGGW) niewyraźna.

W podłożu posadowienia badanych obiektów na kampusie SGGW wyróżniono pięć zespołów warstw. Na podstawie tych gruntów, po ustaleniu litologii i stanu, wyznaczono następujące warstwy geotechniczne (Dokumentacja $^{1}$ z Katedry Geoinżynierii SGGW) (Lechowicz, Rabarijoely 2000):

- I zespół - zawiera piaski glacifluwialne z okresu zlodowacenia warty,

- II zespół - zawiera piaski i gliny zastoiskowe z okresu zlodowacenia warty,

- III zespół - obejmuje brązową glinę glacjalną z okresu zlodowacenia warty,

- IV zespół - zawiera szarą glinę glacjalną z okresu zlodowacenia odry,

- V zespół - najstarszy z nawierconych, obejmuje piaski fluwialne z okresu interglacjału mazowieckiego.

Wymienione wyżej pakiety zostały przedstawione na przekroju geotechnicznym na rycinie 4 . Biorąc pod uwagę właściwości fizyczne i mechaniczne gruntów, na terenie kampusu SGGW wydzielono w podłożu 5 warstw geotechnicznych (ryc. 4). Warstwę I tworzą utwory fluwioglacjalne zlodowacenia warty $\left.{ }^{\mathrm{fg}} \mathrm{Q}_{\mathrm{p}} \mathrm{W}\right)$ - piaski średnie i drobne, średnio zagęszczone o wartościach stopnia zagęszczenia $I_{D}$ w zakresie $0,35 \div 0,55$ oraz piaski gliniaste i gliny piaszczyste, jak również pyły w stanie twardopla-

Dokumentacja znajduje się w Katedrze Geoinżynierii, SGGW. stycznym o wartościach stopnia plastyczności $\mathrm{I}_{\mathrm{L}}$ od 0,15 do 0,20 . Warstwę II stanowią osady ablacyjne lądolodu zlodowacenia warty $\left({ }^{\mathrm{b}} \mathrm{Q}_{\mathrm{p}} \mathrm{W}\right)$ - piaski średnie i drobne średnio zagęszczone o $I_{D}=0,3 \div 0,5$, gliny piaszczyste (spływowe) oraz piaski gliniaste $\mathrm{w}$ stanie twardoplastycznymi o $\mathrm{I}_{\mathrm{L}}$ $=0,0 \div 0,20$ i plastycznym o $I_{L}=0,25 \div 0,54$. Warstwa III to brązowa glina glacjalna $\mathrm{z}$ okresu zlodowacenia warty $\left({ }^{\mathrm{g} Q p W}\right)$ - gliny piaszczyste $\mathrm{w}$ stanie twardoplastycznym o wartościach $\mathrm{I}_{\mathrm{L}}$ od 0,0 do 0,11 . Warstwa IV z kolei to szara glina glacjalna z okresu zlodowacenia odry ( $\left.{ }^{\mathrm{g}} \mathrm{QpO}\right)$ - gliny piaszczyste z głazikami w stanie twardo plastycznym o wartościach $\mathrm{I}_{\mathrm{L}}$ od 0,0 do 0,12 . Warstwy III i IV są podobne pod względem plastyczności, ale wyraźnie różnią się zawartością frakcji piaskowej. Gliny piaszczyste warstwy III zawierają kilka procent więcej frakcji piaskowej, co łącznie z analizą wyników sondowań CPT i DMT było podstawą propozycji rozdzielenia tych warstw w podłożu. Warstwę V stanowią osady rzeczne interglacjału mazowieckiego $\left({ }^{\mathrm{f}} \mathrm{Q}_{\mathrm{p}} \mathrm{M}\right)$ - piaski drobne i średnie, w stropie warstwy bardzo zagęszczone o $\mathrm{I}_{\mathrm{D}}=0,8 \div 0,9$.

\section{Analiza uzyskanych wyników badań dylatometrycznych}

Celem przeprowadzonych obliczeń jest wydzielenie warstw geotechnicznych (korzystając z dotychczasowych doświadczeń Katedry Geoinżynierii SGGW; Lechowicz, Rabarijoely 2000), wyznaczenie modułu ścinania $G_{o}$ oraz wybranych parametrów wytrzymałościowych: współ- 


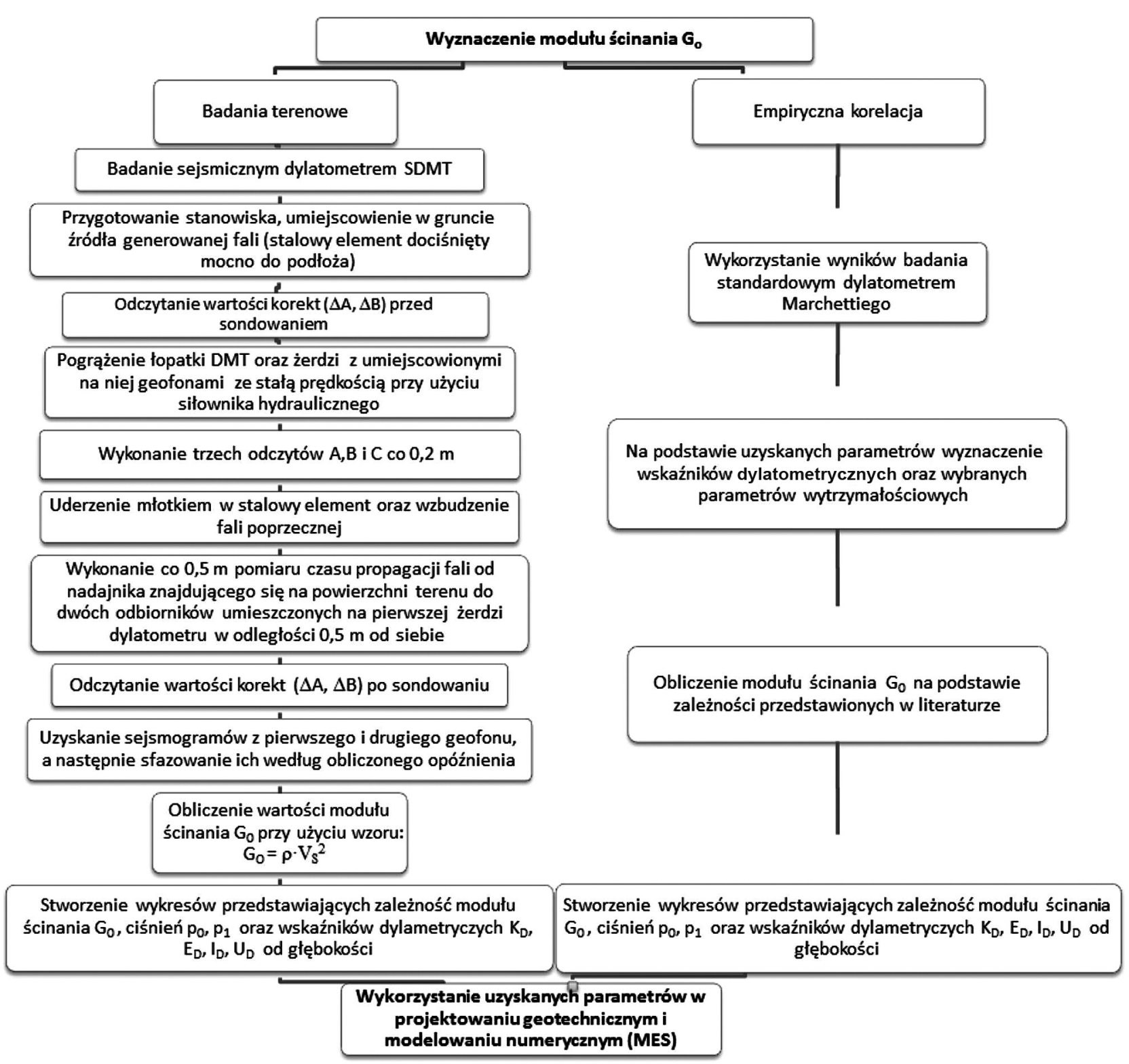

Ryc. 5. Schemat prezentujący sposoby wyznaczenia modułu ścinania $G_{\circ}$

Fig. 5. The algorithm diagram showing the ways of determining the shear modulus $G_{o}$

czynnika prekonsolidacji OCR, wytrzymałości na ścinanie bez odpływu $\tau_{\text {fu}}$, modułu ściśliwości $M$, kąta tarcia wewnętrznego $\phi$ ', spójności c' oraz stopnia zagęszczenia $I_{D}$. Przeprowadzono badania terenowe i laboratoryjne (m.in. wiercenia, sondowania DMT oraz SDMT). Rezultatem jest zbiór wyników, których wnikliwa analiza pozwoli na wyznaczenie modułu ścinania $\mathrm{G}_{\mathrm{o}}$ oraz umożliwi określenie historii naprężeń gruntu.

\section{Proponowana metoda wyznaczenia modułu ścinania $G_{0}$}

\section{Generalna zasada oraz opis metody}

Moduł ścinania $\mathrm{G}_{\mathrm{o}}$ możemy wyznaczyć na dwa różne sposoby. Pierwszą możliwością jest uzyskanie prędkości fali poprzecznej $\mathrm{V}_{\mathrm{s}}$ pomierzonej poprzez badania terenowe przy użyciu fali sejsmicznej (np. sejsmiczny dylatometr SDMT). Następnie, korzystając ze wzoru (3) pozwalającego obliczyć wartość modułu ścinania $G_{0}$ na podstawie gęstości gruntu i prędkości fali poprzecznej $\mathrm{V}_{\mathrm{s}}$, jesteśmy w stanie uzyskać rzeczywistą wartość modułu ścinania $\mathrm{G}_{\mathrm{o}}$. Drugi sposób oparty jest na wyznaczeniu modułu ścinania $\mathrm{G}_{\mathrm{o}}$ na podstawie empirycznych korelacji zawartych w literaturze. Zależności te wykorzystują parametry uzyskane ze standardowego sondowania dylatometrem Marchettiego. Te dwa sposoby zostały przedstawione na rycinie 5 .

\section{Propozycje nomogramów}

Na podstawie pomierzonych wartości modułu ścinania $G_{o}$ za pomocą sejsmicznego dylatometru SDMT dla obiektów zlokalizowanych na terenie kampusu SGGW oraz na 


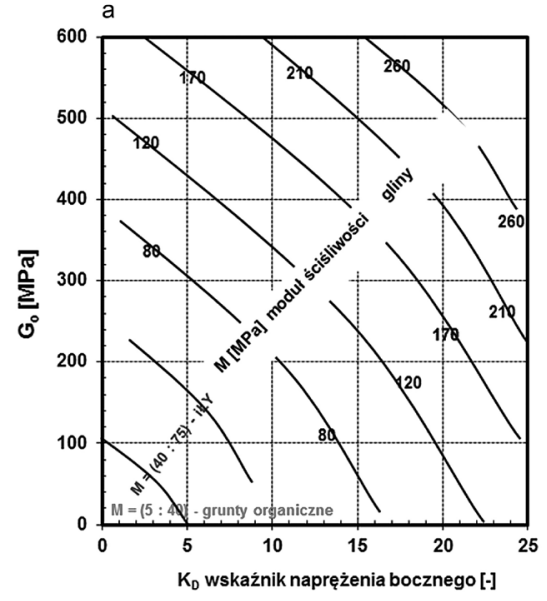

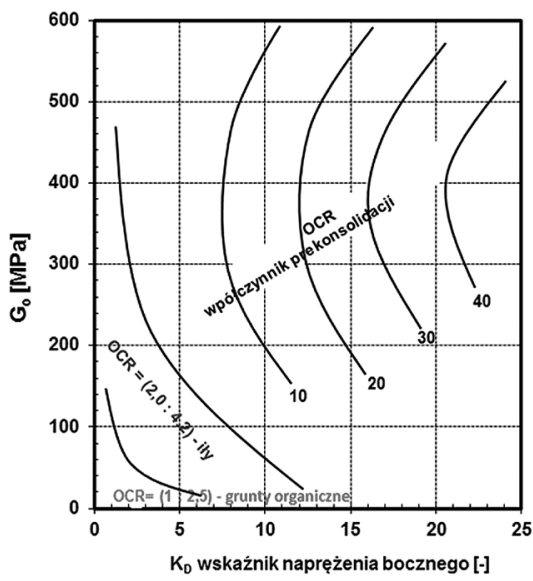

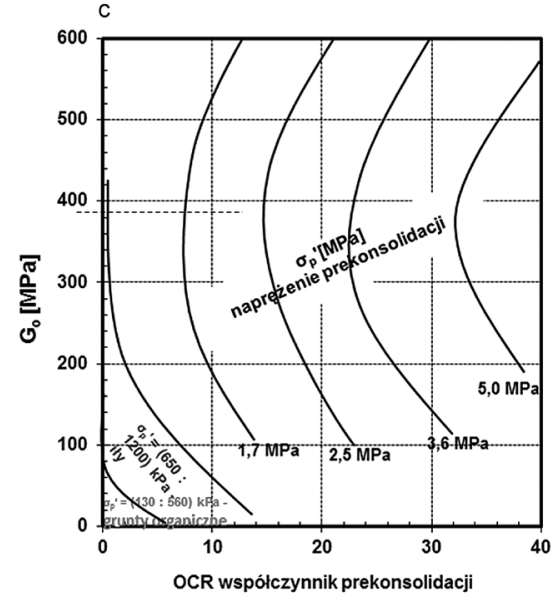

Ryc. 6. Nomogram przedstawiający zmienność: a - modułu ściśliwości M dla gruntów mineralnych i organicznych, b - naprężenia prekonsolidacji $\sigma_{p}^{\prime}$ dla gruntów mineralnych i organicznych, c - współczynnika prekonsolidacji OCR dla gruntów mineralnych i organicznych

Fig. 6. Nomogram CHART showing variability: $\mathrm{a}$ - a constrained modulus $\mathrm{M}$ for mineral and organic soil, $\mathrm{b}$ - overconsolidation stress $\sigma_{\mathrm{p}}^{\prime}$ for mineral and organic soil, $\mathrm{c}$ - overconsolidation ratio OCR for mineral and organic soil

poligonie doświadczalnym Stegny w Warszawie zaproponowano trzy nomogramy (ryc. 6a, b i c).

Pierwszy nomogram (ryc. 4a) prezentuje zmienność modułu ściśliwości $\mathrm{M}$ w zależności od modułu ścinania $\mathrm{G}_{\mathrm{o}}$ i wskaźnika naprężenia bocznego $\mathrm{K}_{\mathrm{D}}$. Zauważyć można, że gytje oraz namuły przy wartości $\mathrm{G}_{\mathrm{o}}$ oscylującej w granicach $50 \mathrm{MPa}$ osiągają wartości modułu ściśliwości z przedziału 5 $\div 40 \mathrm{MPa}$. Wyższymi wartościami modułu ściśliwości znajdującymi się w przedziale $28 \div 75$ charakteryzują się iły dla modułu ścinania na poziomie od 50 do $160 \mathrm{MPa}$. Największe wartości modułu ściśliwości osiągają gliny piaszczyste. Jak podano na nomogramie, wartości parametru M mają dużą rozpiętość - od około 80 do około $250 \mathrm{MPa}$ dla wartości modułu ścinania $G_{\circ}$ oscylującej w granicach od około 120 do $600 \mathrm{MPa}$.

Kolejny nomogram (ryc. 6b) przedstawia zmienność naprężenia prekonsolidacji $\sigma_{\mathrm{p}}$ ' $\mathrm{w}$ zależności od modułu ścinania $G_{o} i$ współczynnika prekonsolidacji $O C R=$ $\sigma_{\mathrm{p}}^{\prime} / \sigma_{\mathrm{vo}}^{\prime}$. Na podstawie powyższego nomogramu można stwierdzić, że gytje oraz namuły przy wartości $\mathrm{G}_{\mathrm{o}}$ oscylującej w granicach $50 \mathrm{MPa}$ osiągają wartości modułu ściśliwości z przedziału $0,1 \div 0,5 \mathrm{MPa}$. Wyższymi wartościami modułu ściśliwości mieszczącymi się w przedziale $0,4 \div 1,2 \mathrm{MPa}$ charakteryzują się iły dla modułu ścinania na poziomie od 30 do $160 \mathrm{MPa}$. Najwyższe wartości modułu ściśliwości osiągają gliny piaszczyste. Jak widać na nomogramie, wartości naprężenia prekonsolidacji mają duży zakres - od około 1,0 do około 4,0 MPa dla wartości modułu ścinania $\mathrm{G}_{\mathrm{o}}$ oscylującej w granicach od około 120 do $600 \mathrm{MPa}$.

Kolejny nomogram (ryc. 6c) ukazuje zmienność współczynnika prekonsolidacji OCR w zależności od modułu ścinania $G_{o} i$ wskaźnika naprężenia bocznego $K_{D}$. Na podstawie powyższego nomogramu można zinterpretować, że gytje oraz namuły przy wartości $\mathrm{G}_{\mathrm{o}} \mathrm{w}$ granicach $50 \mathrm{MPa}$ osiągają wartości modułu ściśliwości z przedziału $0,8 \div 2,5$. Wyższymi wartościami modułu ściśliwości mieszczącymi się w przedziale $2,0 \div 4,2$ charakteryzują się iły dla modułu ścinania na poziomie od 40 do $180 \mathrm{MPa}$. Najwyższe wartości modułu ściśliwości osiągają gliny piaszczyste. Jak zaznaczono na nomogramie, współczynnik prekonsolidacji ma przedział wartości od około 10 do około 20 dla wartości modułu ścinania $G_{o}$ oscylującej w granicach od około 160 do $600 \mathrm{MPa}$.

\section{Podsumowanie i wnioski}

Celem przeprowadzenia badań dylatometrycznych na terenie osiedla Stegny było dostarczenie dodatkowych informacji z innych badań, np. SCPT (piezostożek sejsmiczny) czy z badań laboratoryjnych trójosiowych za pomocą elementu bender dotyczących podłoża iłów plioceńskich. Wydział Geologii UW i Instytut Technik Budowlanych, a także Katedra Geoinżynierii SGGW wykonały w tym miejscu sondowania dylatometryczne, korzystając ze wspólnego poletka doświadczalnego na terenie osiedla Stegny. W obrębie kampusu SGGW badania dylatometryczne były pomocne w ustaleniu parametrów odkształceniowych i wytrzymałościowych dla nowo powstających budynków oraz przy dobudowaniu nowych obiektów obok już istniejących (III etap budowy biblioteki, podziemny parking). Zarówno na osiedlu Stegny, jak i na kampusie SGGW do posadowienia obiektów inżynierskich zalecane było stosowanie I i II kategorii geotechnicznej.

Moduł ścinania jest parametrem charakteryzującym sztywność gruntu. Jest on niezbędny do wyznaczenia stanu naprężeń oraz określenia wielkości odkształceń dla projektowanych budowli. Parametry sprężyste, takie jak moduł ścinania, są wykorzystywane w świecie m.in. do prognozowania osiadań obiektów inżynierskich. Otrzymane przy ich zastosowaniu wartości osiadań (np. z użyciem modelowania MES) są znacznie bardziej zbliżone do wartości rzeczywistych pomierzonych niż wartości osiadań otrzymane przy wykorzystaniu np. standardo- 
wych modułów edometrycznych. Warto zaznaczyć, że moduł ścinania $G_{o}$ jest niezwykle ważnym parametrem przy rozwiązywaniu problemów granicznych wartości takich, jak:

- reakcja sejsmiczna gruntów na trzęsienia ziemi,

- dynamiczna interakcja pomiędzy gruntem i fundamentami,

- projektowanie specjalnych fundamentów, których granica stosowalności pozwala na bardzo małe przemieszczenia.

Praktycznie moduł ścinania $\mathrm{G}_{\mathrm{o}}$ obliczony na podstawie empirycznych korelacji może być na równi stosowany do obliczeń sztywności gruntu jak ten uzyskany bezpośrednio w sondowaniach sejsmicznym dylatometrem SDMT.

Aby wyznaczyć sztywność podłoża przy użyciu modułu ścinania w gruntach mineralnych i organicznych, można wykorzystać nomogramy zaproponowane w tym artykule.

\section{Podziękowania}

Praca naukowa finansowana ze środków na naukę w latach 2012-2015 z projektu badawczego NCN: UMO-2011/03/D/ST8/04309. Autorzy dziękują trzem anonimowym recenzentom za wnikliwe uwagi.

\section{Literatura}

Amoroso, Monaco P., Marchetti S., 2012. Use of the Seismic Dilatometer (SDMT) to estimate in situ G- $\gamma$ decay curves in various soil types. Incontro Annuale dei Ricercatori di Geotecnica 2012 IARG 2012 Padova, 2-4 luglio 2012

Bajda M., Lech M., Markowska-Lech K., 2008. The use of resistivity and seismic cone penetration tests for site characterization. Ann. Warsaw Univ. of Life Sci. - SGGW, Land Reclam. 40: 87-96.

Campanella R.G., Stewart W.P., 1992. Seismic cone analysis using digital signal processing for dynamic site characterization. Canad. Geotech. 29(3): 477-486.

Dokumentacja geotechniczna w sprawie warunków gruntowych i wodnych na terenie przeznaczonym pod dwa projektowane budynki laboratoryjno-dydaktyczne SGGW w Warszawie, 2001. Katedra Geoinżynierii SGGW.

Hardin B.O., Black W.L., 1968. Vibration modulus of normally consolidated clay (closure). Journal of the Soil Mechanics and Foundations Division 94(2): 353-369.

Hardin B.O., 1978. The nature of stress-strain behaviour of soils. Stateof-the-art report. Proc. Spec. Conf. on Earthquake Engineering and Soil Dynamics: 3-90.

Hepton P., 1988. Shear wave velocity measurements during penetration testing. Proc. Penetration Testing in the UK: 275-278.

Lechowicz Z., Rabarijoely S., 2000. Wykorzystanie badań dylatometrycznych do wyznaczania warstw geotechnicznych podłoża organicznego. Mat. na ,Jubileuszowa Sesja Naukowa. Geotechnika w Budownictwie i inżynierii środowiska", Gdańsk: 253-258.

Marchetti S., 1980. In Situ Tests by Flat Dilatometer. J. Geotech. Eng. Div., ASCE, 106, GT3: 299-321.

Marchetti S., Monaco P., Totani G., Marchetti D., 2008. In Situ Tests by Seismic Dilatometer (SDMT). ASCE Geot. Special Publication GSP 170 honoring Dr. J.H. Schmertmann. New Orleans, March: 9-12.

Martin G.K., Mayne P.W., 1997. Seismic Flat Dilatometer Tests in Connecticut Valley Varved Clay. ASTM Geotech. Testing J. 20(3): 357-361.

Mayne P.W., Schneider J.A., Martin G.K., 1999. Small- and large-strain soil properties from seismic flat dilatometer tests. Proc. 2nd Int. Symp. on Pre-Failure Deformation Characteristics of Geomaterials. Torino 1: 419-427.

Monaco P., Marchetti S., Totani G., Marchetti D., 2009. Interrelationship between Small Strain Modulus $\mathrm{G}_{\mathrm{o}}$ and Operative Modulus. IS-Tokyo2009. International Conference on Performance-Based Design in Earthquake Geotechnical Engineering. June 2009.

Morawski W., 1984. Osady wodno-morenowe. Prace Instytutu Geologicznego 108.

Rabarijoely S. i in., 2012. Dobór parametrów wytrzymałościowo-odkształceniowych gruntów spoistych w projektowaniu geotechnicznym według Eurokodu $7 \mathrm{z}$ wykorzystaniem analizy bayesowskiej. Projekt badawczy MNiSzW nr N N506 432436, MS.

Różycki S.Z., 1972. Plejstocen Polski środkowej na tle przeszłości w późnym trzeciorzędzie. PWN, Warszawa.

Różycki S.Z., Sujkowski Z., 1936. Profile geologiczne przez Warszawę. Zarząd Miejski w Warszawie.

Sarnacka Z., 1976. Objaśnienia do szczegółowej mapy geologicznej Polski w skali 1:50 000. Arkusz Piaseczno. Instytut Geologiczny, Warszawa.

Sarnacka Z., 1992. Stratygrafia osadów czwartorzędowych Warszawy i okolic. Prace PIG 138: 36.

Shibuya S., Tatsuoka F., Teachavorasinskun S., Kong X.J., Abe F., Kim Y.S., Park C.S., 1992. Elastic Deformation Properties of Geomaterials, Soils and Foundations. Journal of the Japanese Society of Soil Mechanics and Foundation Engineering 32(3): 23-46. 